\title{
Ines Załęska
}

Akademia im. Jana Długosza w Częstochowie https://doi.org/10.18778/8142-463-9.17

\section{Reklama na wagę złota, czyli o marketingowych trikach supermarketów}

Internet to współcześnie bardzo potężne medium reklamowe. Specyfika reklamy internetowej ma jednak swoje plusy i minusy. Warto zwrócić uwagę na fakt, że poprzez swoją dynamiczność, interaktywność oraz brak ograniczeń geograficznych i czasowych staje się ona dominującą formą na rynku marketingowym. Z drugiej jednak strony, nie każdy odbiorca docelowy obejrzy tę reklamę, jeśli nie korzysta on z internetu wystarczająco często. Ponadto użytkownicy mediów świadomie wybierają treści, które chcą oglądać, stąd potencjalny reklamodawca nie może mieć pewności, że jego przekaz trafi do wszystkich zainteresowanych tematem. Aktywni na rynku reklamodawcy decydują się obecnie na wykorzystanie kanałów social media, które pomagają rozprzestrzenić treści reklamowe na szerszą skalę. Zagadnienie marketingu internetowego to temat bardzo obszerny. Zapotrzebowanie rynku na kreatywną reklamę rośnie, a potencjalnych kanałów przybywa. Współczesne media społecznościowe kreują obecnie nowy model przepływu informacji. Celem artykułu jest zbadanie wybranych kampanii reklamowych supermarketów Lidl, Biedronka i Tesco, ze szczególnym uwzględnieniem działań prowadzonych na portalu społecznościowym Facebook.

Philip Kotler, uznany teoretyk marketingu, szczegółowo omawia problem organizacji e-marketingu. Wśród takich działań, jak stworzenie witryny internetowej, posiadanie poczty elektronicz- 
nej, wykorzystanie reklam w celu promocji marki, wymienia on także stworzenie portali społecznościowych, które mają pomóc firmie zaistnieć na rynku [Kotler, Armstrong 2012: 35-38]. Według badań Jona Reeda współczesny internauta poświęca dziesięć minut w ciągu godziny na korzystanie z social media [Reed 2011: 155]. Firmy, które nie wykorzystują potencjału serwisów społecznościowych, nie mogą liczyć na bezpośrednie reakcje potencjalnych klientów. Takie social media jak Facebook, Twitter, Snapchat, Instagram rozwijają się bardzo dynamicznie i nieustannie zyskują nowych użytkowników. Wybór odpowiedniego networkingowego serwisu społecznościowego nie jest jednak prosty. Musi on pasować do marki i jej sposobów reklamowania się, ale też do potencjalnej grupy odbiorców docelowych. Wartości, które są realizowane przez firmy powinny być tożsame z tymi, których oczekują konsumenci [Rak 2012: 407-416]. Networking internetowy to nie tylko stworzenie profilu firmy na portalu społecznościowym, lecz także chroniczne udostępnianie pewnych informacji, regularna aktualizacja statusów (krótkich postów), tworzenie wydarzeń i zarządzanie nimi, udostępnianie wybranych zdjęć i materiałów wideo. Zagadnienie obejmuje też promowanie produktów i usług w reklamie. Warto wyróżnić marketing szeptany (whisper marketing, buzz marketing) jako taką formę marketingu, która może przynieść znaczące korzyści dla sieci supermarketów. Reed nazywa takie działania „Świętym Graalem marketerów” [Reed 2011: 157]. Kiedy internauci zaczynają sobie nawzajem polecać produkty, aktywnie komentują posty, udostępniają treści reklamowe, technika marketingu szeptanego działa bez zarzutu. Informacje docierają do szerszej grupy odbiorców, a sklepy pozyskują nowych klientów.

Supermarkety proponują oryginalne strategie marketingowe. Różnią się one w zależności od tego, jaki efekt końcowy mają wywołać. Marketing internetowy, obejmujący networking społecznościowy, jest inny od strategii w sklepach stacjonarnych. Jeżeli niewielki dyskont chce zyskać miano supermarketu, musi zadbać o klienta. Rebranding marki to wszystkie działania, które mają - w teorii - pro- 
wadzić do repozycjonowania danej sieci sklepów na tle innych. Zmiany wizualne to np. poprawienie logo firmy, natomiast szczególnie istotne jest to, jak zmienia się postrzeganie marki przez konsumentów ${ }^{1}$. Podczas wizyty w supermarkecie uwagę klienta zwracają najczęściej produkty, które są wyeksponowane, oznaczone hasłem „promocja” lub te, które wyróżniają się na tle innych. Zarządzanie ekspozycją, czyli zmiany na półkach (lokowanie produktów), to jedna z zasad visual merchandisingu. Aby wyróżnić się na tle konkurencji, supermarkety muszą nieustannie podejmować kreatywne działania marketingowe. Takie czynniki, jak zastosowanie kolorów wewnątrz sklepu czy dobre oświetlenie lokalu, mogą mieć pozytywny wpływ na samopoczucie nabywcy. Podkreślają one również ekspozycję towarów [Diamond, Diamond 2007: 261-262]. Praktyki marketingowe ze sklepów stacjonarnych są widoczne także w internecie. Administratorzy stron supermarketów lokują produkty tak, aby przyciągały one uwagę klienta w pożądany sposób. Zastosowane strategie pozwalają sprzedać towar, który zalega w magazynach lub kończy się termin jego przydatności do spożycia.

Dyskurs marketingowy możemy analizować na kilku płaszczyznach. Szczególnie istotne znaczenie dla rozwoju firmy ma slogan reklamowy, który po pewnym czasie kojarzy się już tylko z jedną marką. Słowa klucze odgrywają ważną rolę w przekazie reklamowym, niektóre zyskują miano kultowych. Slogany pojawiają się regularnie w różnych mediach, są elementem charakterystycznym kampanii społecznych, stanowią o sile sieci supermarketu. Odbiorcy zapamiętują je podświadomie. Hasłem reklamowym supermarketu Lidl jest obecnie „Lidl - mądry wybór”. Jak dotąd jest to najlepszy pomysł niemieckiej sieci supermarketów. Hasło sygnalizuje, że konsument mądrze wybiera, jeśli idzie na zakupy

1 Jarosław Filipek, autor tekstu Od dyskontu do supermarketu. Rebranding Biedronki, zwraca uwagę na transformację jednej z sieci supermarketów, której strategia przełożyła się na popularność sklepu na polskim rynku. Jest to interesujący artykuł w odniesieniu do tematu działań marketingowych supermarketów [Filipek 2012]. 
do tego właśnie sklepu. Wcześniej supermarket proponował takie slogany jak „Lidl jest tani” czy „Lidl ceni jakość”. Pierwsze hasło nie zostało dobrze odebrane przed konsumentów, ponieważ kojarzyło się im z produktami niskiej jakości, a nie z niskimi cenami. Drugie okazało się mało atrakcyjne. Tesco, brytyjska sieć supermarketów, jako swoje hasło wybrało niegdyś „Dużo, tanio, Tesco”. W uproszczonym tłumaczeniu slogan oznacza, że w Tesco konsument może kupić dużo produktów za niewielką kwotę. Wyrazy $\mathrm{w}$ haśle ułożone są w porządku rosnącym. Dwie pierwsze cechy odnoszą się do korzyści, które wynikają z robienia zakupów w tej sieci supermarketów, natomiast zamiast trzeciej cechy pojawia się nazwa sklepu. Taka forma sloganu jest atrakcyjna wizualnie, zaskakująca i łatwo zapada w pamięć. Obecnie Tesco wykorzystuje hasło: „Ciesz się tym, co dobre z TESCO”, jednak nie jest ono szeroko promowane w mediach. Również Biedronka, której właścicielem jest portugalskie Jerónimo Martins, wykorzystuje hasło przywodzące na myśl niską cenę produktów. Slogan „Biedronka - codziennie niskie ceny” jest prosty i to jest jego największą siłą. Uniknięcie słowa „tani” w haśle reklamowym jest sprytnym zabiegiem marketingowym. Informacja, że w Biedronce można codziennie kupić produkty za mniejszą kwotę ma wpływ na decyzję nabywcy, który chce zaoszczędzić na zakupach. Sklep pozycjonuje się jako taki, w którym codziennie są niskie ceny, a nie tak jak u konkurencji - w określonym czasie. Inną taktykę marketingową zastosował natomiast Carrefour, francuska sieć supermarketów. Nowe hasło sklepu to „Carrefour - pozytywnie każdego dnia”. Wykorzystane słowo pozytywnie jest sygnałem, że zakupy w tym supermarkecie to najlepszy wybór. Klienci powinni wybrać Carrefour nie tylko ze względu na asortyment - liczy się też wysoki standard personelu. Każdy, kto zdecyduje się na zakupy w Carrefourze, będzie w pozytywnym nastroju. Ponadto sklep nakręcił teledysk korporacyjny, który był elementem kampanii społecznej. Projekt wymagał zgrania 50 osób na planie zdjęciowym w jeden dzień. Hasła, które pomocniczo padały w nagraniu to: „Pomagamy naszym klientom w osiąganiu lepszej jakości życia”, 
„Wybierz Carrefour i zmieniaj świat na lepsze”, „Klienci i konsumenci są w centrum zainteresowania naszych działań”, „Cenimy ludzi, dla których biznes to zarówno zysk, jak i sposób zmiany świata na lepsze”, „Tylko szczęśliwi ludzie mogą być dobrymi pracownikami, motywujemy do rozwoju osobistego i zdobywania nowych kompetencji, stwarzamy szanse tym, którzy otrzymują je niezwykle rzadko”, „Naszą pasją jest wygrywanie każdego dnia”, „Zawsze o krok przed konkurencją”, „Carrefour to coś więcej niż sklep. To zaangażowanie, troska i pozytywne nastawienie do świata" 2 .

Podane wyżej hasła reklamowe różnych supermarketów powinny dobrze kojarzyć się potencjalnemu konsumentowi. Analizując wyróżnione slogany, można zauważyć, że sklepy w większości odnoszą się do niskiej ceny produktów. Jest to sygnał, że najbardziej istotną kwestią dla konsumenta jest właśnie to, ile musi on przeznaczyć pieniędzy na zakupy. Sklep, który oferuje dobre produkty za niską cenę jest najatrakcyjniejszy w opinii osób robiących zakupy.

Działalność marketingowa supermarketów jest najbardziej widoczna na portalach społecznościowych. Ta przestrzeń internetu pozwala sklepom rozwinąć swoje możliwości w ramach e-marketingu. Obecnie najprężniej działającą siecią supermarketów jest Lidl. Od jesieni ubiegłego roku sklep prowadzi bardzo kreatywną kampanię na Facebooku. Publikowane posty zawierają nie tylko inspirujące tytuły i kolorowe zdjęcia produktów, lecz także dowcipne slogany. Gra słowna, którą proponuje Lidl jest dostosowana do oczekiwań polskiego odbiorcy. Nie tylko bawi ona konsumenta, ale i skutecznie wpływa na niego, aby kupił reklamowany produkt. Kreatywne posty na Facebooku pełnią przede wszystkim funkcję rozrywkową, niektóre z nich są jednak interesujące z językoznawczego punktu widzenia.

2 Film korporacyjny sieci supermarketów Carrefour: http://www.ostro-video.pl/portfolio/carrefour-pozytywnie-kazdego-dnia (dostęp: 18.04.2018). 
Tabela 1. Hasła, które pełnią funkcję rozrywkową

\begin{tabular}{|c|c|c|c|}
\hline Produkt & $\begin{array}{l}\text { Co przedstawia } \\
\text { grafika? }\end{array}$ & $\begin{array}{l}\text { Hasło } \\
\text { na grafice }\end{array}$ & $\begin{array}{l}\text { Podpis } \\
\text { pod grafiką }\end{array}$ \\
\hline $\begin{array}{l}\text { Opakowanie } 10 \\
\text { jajek klasy L }\end{array}$ & $\begin{array}{l}\text { opakowanie } \\
\text { jajek }\end{array}$ & JAJAJE & $\begin{array}{l}\text { „O jaja je! Od } \\
19.03 \text { w Lidlu } \\
\text { mamy promocję } \\
\text { na jaja klasy L dla } \\
\text { wszystkich tych, } \\
\text { którzy jaja jedzą". }\end{array}$ \\
\hline $\begin{array}{l}\text { Akumulatorowy } \\
\text { odkurzacz } \\
\text { na mokro } \\
\text { i na sucho }\end{array}$ & $\begin{array}{l}\text { mały podręczny } \\
\text { odkurzacz, który } \\
\text { może służyć } \\
\text { do robienia } \\
\text { porządków } \\
\text { na małych } \\
\text { powierzchniach }\end{array}$ & ODKURZECZ & $\begin{array}{l}\text { „Odkurzecz do } \\
\text { różnych rzeczy } \\
\text { - mały, poręczny } \\
\text { i poradzi sobie } \\
\text { z zabrudzeniami } \\
\text { na mokro i sucho. } \\
\text { Co tu dużo } \\
\text { pisać - warto go } \\
\text { mieć w swoim } \\
\text { samochodzie czy } \\
\text { domu, a możecie } \\
\text { go kupić od } 17.03 \\
\text { w Lidlu!”. }\end{array}$ \\
\hline $\begin{array}{l}\text { Spodnie } \\
\text { cygaretki }\end{array}$ & $\begin{array}{l}\text { niebieskie } \\
\text { spodnie } \\
\text { cygaretki }\end{array}$ & ALEGANCKO & $\begin{array}{l}\text { „Ale będzie ale- } \\
\text { gancko w Lidlu! } \\
\text { A wszystko to od } \\
15.03 \text { za sprawą } \\
\text { nowej kolekcji sty- } \\
\text { lowych ubrań dla } \\
\text { kobiet i mężczyzn, } \\
\text { które idealnie } \\
\text { nadają się do } \\
\text { pracy”. }\end{array}$ \\
\hline
\end{tabular}

Źródło: opracowanie własne na podstawie obserwacji i z wykorzystaniem źródeł internetowych (oficjalna strona Lidl Polska na Facebooku, https:// www.facebook.com/lidlpolska, dostęp: 18.04.2018).

Hasła pełniące funkcję rozrywkową (tab. 1) są często kontaminacjami wyrazowymi, tak jak na przykład: odkurzecz („odkurzacz” i „rzecz”), alegancko (wykrzyknik „ale” i przysłówek „elegancko”). Elementy rozrywkowe mogą również przejawiać się w takich złożeniach, jak jajaje, które charakteryzują się melodyjnością i łatwością w przyswajaniu. 
Tabela 2. Hasła, które przywodzą na myśl efekt wykorzystania danego produktu

\begin{tabular}{|c|c|c|c|}
\hline Produkt & $\begin{array}{l}\text { Co przedstawia } \\
\text { grafika? }\end{array}$ & $\begin{array}{l}\text { Hasło } \\
\text { na grafice }\end{array}$ & $\begin{array}{l}\text { Podpis } \\
\text { pod grafiką }\end{array}$ \\
\hline Proszek Ariel & $\begin{array}{l}\text { opakowanie } \\
\text { proszku Ariel do } \\
\text { białego i koloru }\end{array}$ & NA CZYSTO & $\begin{array}{l}\text { „Jedno pudełko } \\
\text { w rozmiarze XXL, } \\
\text { czyli wychodzi } \\
\text { około } 67 \text { prań na } \\
\text { czysto". }\end{array}$ \\
\hline $\begin{array}{l}\text { Zestaw } \\
\text { wędkarski } \\
\text { z wyposażeniem }\end{array}$ & $\begin{array}{l}\text { zestaw } \\
\text { wędkarski } \\
\text { z wieloma } \\
\text { elementami }\end{array}$ & $\begin{array}{l}\text { KRÓL } \\
\text { WODY }\end{array}$ & $\begin{array}{l}\text { „Mamy tu } \\
\text { wielbicieli } \\
\text { wędkarstwa? Od } \\
19.03 \text { będziecie } \\
\text { mogli wypłynąć } \\
\text { na szerokie wody } \\
\text { i łapać same } \\
\text { grrruuuuube } \\
\text { ryby!". }\end{array}$ \\
\hline $\begin{array}{l}\text { Orzechy } \\
\text { nerkowca }\end{array}$ & $\begin{array}{l}\text { paczka } \\
\text { z orzechami } \\
\text { nerkowca }\end{array}$ & CHRUP & $\begin{array}{l}\text { „No to chrup! } \\
\text { Tak właśnie zrób, } \\
\text { bo te najczęściej } \\
\text { kupowane } \\
\text { orzechy w Polsce } \\
\text { dostaniecie } \\
\text { w Lidlu w specjal- } \\
\text { nej cenie już od } \\
5.03 ! " .\end{array}$ \\
\hline
\end{tabular}

Źródło: jak do tab. 1.

Hasła przywodzące na myśl efekt wykorzystania danego produktu (tab. 2) są twórcze. Jeśli internauta zrobi pranie z wykorzystaniem proszku Ariel, będzie miał czyste ubrania (na czysto), jeśli kupi zestaw wędkarski, stanie się królem wody, jeżeli natomiast spróbuje orzechów nerkowca, będzie chrupać - chrup (odgłos charakterystyczny przy łamaniu, kruszeniu czegoś).

Hasła-neologizmy (tab. 3) to słowa, które nie znajdują się we współczesnym Słowniku języka polskiego: iście (skrócona forma od słowa „kiście”), kicak (w odniesieniu do czynności, jaką wykonuje zająć - skakanie, kicanie), olejkado (kontaminacja dwóch słów: „olej” i „awokado”). 
Tabela 3. Hasła-neologizmy

\begin{tabular}{|l|l|l|l|}
\hline Produkt & $\begin{array}{l}\text { Co przedstawia } \\
\text { grafika? }\end{array}$ & $\begin{array}{l}\text { Hasło } \\
\text { na grafice }\end{array}$ & Podpis pod grafiką \\
\hline $\begin{array}{l}\text { Winogrona } \\
\text { czerwone } \\
\text { na wage }\end{array}$ & $\begin{array}{l}\text { Kiść winogron } \\
\text { czerwonych }\end{array}$ & IŚCIE & $\begin{array}{l}\text { "Jest iście pięknie } \\
\text { i pysznie, bo w tę sobotę } \\
\text { mamy w promocji } \\
\text { winogronowe kiście! [... } \\
\text { Co z tego, że w niedziele } \\
\text { sklepy nieczynne, jak } \\
\text { w sobotę czekają na Was } \\
\text { te pyszności!". }\end{array}$ \\
\hline $\begin{array}{l}\text { Czekoladowy } \\
\text { zając }\end{array}$ & $\begin{array}{l}\text { Wielkanocny } \\
\text { zając } \\
\text { z czekolady }\end{array}$ & KICAK & $\begin{array}{l}\text { "Sezon na czekokicaki } \\
\text { uważamy za otwarty! } \\
\text { [..] Wiosna i Wielkanoc } \\
\text { zbliżają się wielkimi } \\
\text { krokami, więc warto zao- } \\
\text { patrzyć się w słodkości!". }\end{array}$ \\
\hline $\begin{array}{l}\text { Olej } \\
\text { spożywczy } \\
\text { z awokado }\end{array}$ & $\begin{array}{l}\text { Buteleczka oleju } \\
\text { z awokado }\end{array}$ & OLEJKADO & $\begin{array}{l}\text { "Olej z awokado z serii } \\
\text { Deluxe! Warto go mieć } \\
\text { w swojej kuchni. Znajdzie- } \\
\text { cie go w Lidlu od 12.03". }\end{array}$ \\
\hline
\end{tabular}

Źródło: jak do tab. 1.

Tabela 4. Hasła, które nie są stricte związane z produktem

\begin{tabular}{|l|l|l|l|}
\hline Produkt & $\begin{array}{l}\text { Co przedstawia } \\
\text { grafika? }\end{array}$ & $\begin{array}{l}\text { Hasło } \\
\text { na grafice }\end{array}$ & Podpis pod grafiką \\
\hline $\begin{array}{l}\text { Banany } \\
\text { na wage }\end{array}$ & Banany & TOLEK & $\begin{array}{l}\text { "W tę sobotę stawiamy na } \\
\text { banana! [...] Dlatego też } \\
\text { obniżyliśmy jego cenę!". }\end{array}$ \\
\hline $\begin{array}{l}\text { Wiertarka } \\
\text { stołowa }\end{array}$ & $\begin{array}{l}\text { Wiertarka } \\
\text { stołowa } \\
\text { zelementami }\end{array}$ & STOLNICA & $\begin{array}{l}\text { "Stolnica dla majsterkow- } \\
\text { icza. [...] A raczej wiertarka } \\
\text { stołowa, dzięki której pre- } \\
\text { cyzja to będzie Twoje drugie } \\
\text { imię. W ofercie od 27.01". }\end{array}$ \\
\hline $\begin{array}{l}\text { Płatki } \\
\text { migdałów }\end{array}$ & Paczka migdałów & W MIG & $\begin{array}{l}\text { "W migdałach siła! A z takimi } \\
\text { ciasto przygotujesz w mig! } \\
\text { Zobacz wszystkie produkty } \\
\text { do pieczenia, które zna- } \\
\text { jdziesz w ofercie od 5.03". }\end{array}$ \\
\hline
\end{tabular}

Źródło: jak do tab. 1. 
Hasła, które nie są stricte związane z produktem (tab. 4), mogą nie być zrozumiałe dla internautów. Jeżeli chodzi o banany, hasło Tolek będzie niejasne dla kogoś, kto nie skojarzy powieści Adama Bahdaja Stawiam na Tolka Banana. Książka została też zekranizowana. Stolnica to element wyposażenia kuchni. Jeżeli wykorzystamy to słowo w odniesieniu do wiertarki stołowej, zrozumienie kontekstu może stanowić problem. Podobnie jest z paczką migdałów, która prawdopodobnie znika $w$ mig.

Tabela 5. Hasła, które pełnią funkcję dydaktyczną

\begin{tabular}{|l|l|l|l|}
\hline Produkt & $\begin{array}{l}\text { Co przedstawia } \\
\text { grafika? }\end{array}$ & $\begin{array}{l}\text { Hasło } \\
\text { na grafice }\end{array}$ & Podpis pod grafiką \\
\hline Rzodkiewki & $\begin{array}{l}\text { Pęczek } \\
\text { rzodkiewek }\end{array}$ & PACZEK & $\begin{array}{l}\text { "Pączek czy pęczek } \\
\text { rzodkiewek? Wybieramy } \\
\text { drugą opcję! Pyszne i ru- } \\
\text { miane od 25.02 w Lidlu!". }\end{array}$ \\
\hline $\begin{array}{l}\text { Bluzki } \\
\text { dwwpaku }\end{array}$ & $\begin{array}{l}\text { Czarno-białe } \\
\text { bluzki }\end{array}$ & OUI OUI & $\begin{array}{l}\text { "Dwie bluzeczki we fran- } \\
\text { cuskim stylu? OUI OUI! } \\
\text { Jesteśmy dwa razy na tak! } \\
\text { W końcu Tydzień Fran- } \\
\text { cuski w pełni! W ofercie } \\
\text { od 18.01!". }\end{array}$ \\
\hline Limetki & $\begin{array}{l}\text { Cztery zielone } \\
\text { limetki }\end{array}$ & MONA LI & $\begin{array}{l}\text { "Limetki to prawdziwe ar- } \\
\text { cydzieła wśród cytrusów. } \\
\text { W ten weekend cieszyć } \\
\text { oko będzie również ich } \\
\text { promocyjna cena”. }\end{array}$ \\
\hline
\end{tabular}

Źródło: jak do tab. 1.

Hasła, które pełnią funkcję dydaktyczną (tab. 5) dają internautom dodatkową wiedzę na temat elementów związanych z różnymi dziedzinami nauki. Pytanie „pączek czy pęczek rzodkiewek?” wymaga odpowiedzi odbiorcy, sprawdza jego wiedzę na temat języka polskiego. Słowo oui to francuskie „tak”, wykorzystane jest na grafice ze względu na Tydzień Francuski. Mona Li(sa) to prawdziwe arcydzieło, ale nie wśród cytrusów. Sprytne wykorzystanie słowa mobilizuje odbiorcę treści do zastanowienia się nad sensem grafiki i tekstu narzuconego na nią. 
Na podstawie obserwacji oficjalnego profilu sklepu Lidl w Polsce można jednak zaobserwować, że nie wszyscy rozumieją specyficzną formę reklamy-żartu. W czerwcu ubiegłego roku sklep opublikował grafikę z kilogramowymi torebkami cukru. Zgodnie z postem cena produktu miała zostać obniżona o 33\%, czyli klient za jedno opakowanie miałby zapłacić 1,99 zamiast 2,99. Uwagę klientów zwróciła jednak nie cena produktu, lecz napis na grafice: „Słodki jeżu”. „Słodka cena” cukru - jak ją nazwali prowadzący profil Lidla na Facebooku - nie zmieniła nastawienia niektórych internautów, którzy skomentowali post, uznając go za niepoprawny i obraźliwy w odniesieniu do religii katolickiej:

Jestem ogromnie oburzony Państwa ostatnią akcją reklamową dotyczącą cukru. Naśmiewanie się z Jezusa Chrystusa pod postacią gry słownej wywołuje zdecydowany protest. [...] Jeżeli Państwo postanawiacie tak zachęcać klientów do zakupów w Waszej sieci handlowej, to ja od teraz w proteście postanawiam nie robić zakupów w sieci sklepów LIDL. I będę od tej pory wszem i wobec zniechęcał do zakupów u Was. Bez pozdrowienia, Marek [Lewandowski 2017].

Lidl usunął post, niejako na żądanie internautów. Ponadto zamieścił przeprosiny w związku z opublikowaną grafiką i tekstem. Niedługo później jedna z polskich agencji reklamowych BRANDWEB postanowiła wykorzystać zamieszanie wokół kontrowersyjnego pomysłu Lidla i podzieliła się własnymi pomysłami na hasła produktów spożywczych. Poza grafiką z cukrem („słodki jeżu”), na stronie agencji reklamowej pojawiły się także inne kolorowe posty z różnymi produktami: cytryny (,jezus cytrus”), marchewki („z marchwi wstał”), bobu („bób ojciec”), drożdże („syn drożdży”), mięta („duch z mięty”). Opublikowane zostały z emotikonkami charakterystycznymi dla wirtualnego świata Facebooka (kciuk w górę, serce, rozbawiony, smutny, zły, zdziwiony).

Biedronka również proponuje swoim obserwatorom na Facebooku ciekawe rozwiązania marketingowe. Uważny użytkownik 
social media może mniemać, że sklep zaczerpnął swój pomysł na działania Facebookowe od Lidla. Od niedawna na oficjalnym kanale Biedronki pojawiły się posty z grafiką, dużą liczbą emotikonek i nienaturalnie wielkimi cyframi, które są jednocześnie cenami za produkt. Wychodzą one zza produktów, okalają je, przebijają się na pierwszy plan - są wyraźnie wyeksponowane, co jest związane z budowaniem wiarygodności firmy. Kolorowe posty Biedronki są opisywane w inspirujący sposób: „Z okazji Dnia Kobiet wszystkim Paniom życzymy radości i słodkości. A Panom podpowiadamy - wybrane bombonierki teraz o min. 20\% taniej”, „Wiosenne porządki tuż-tuż.W tym roku może Ci pomóc nasz rewelacyjny mop parowy z pojemnikiem na detergent!”, „Uwaga, kierowcy! Na każdej drodze czekają Was liczne ułatwienia. Praktyczne gadżety samochodowe, narzędzia i akcesoria zwiększą Wasz komfort jazdy. Podjedźcie do Biedronki i sprawdźcie superceny!”, „Kochamy wspaniałe polskie smaki! Prawdziwe jabłka z polskich sadów, aromatyczne pasztety, kiełbasy, knedle... Sprawdź, co przygotowaliśmy w ramach akcji Dumni z tego, co nasze. Kuchnia polska”. Trudno ocenić, czy Biedronka jest kreatywna językowo - publikowane posty są ciekawe i poprawnie napisane, jednak może zbyt zachowawcze.

Tesco, idąc za przykładem innych supermarketów, także zdecydowało się na kampanię opartą na kolorowych obrazkach. Widzimy np. „zadowolonego Jana z wielkanocnym farszem” czy „babcię Anię z uroczystą kaczką”. Są to posty z kampanii Historie pisane smakiem. Przykładowe teksty opisujące posty to: „Wiosna? Święto wszystkich ogrodników. Przygotujcie się na festiwal kopania, pielenia i innych prac ogrodowych. Znajdziecie u nas szeroki wybór narzędzi w wyjątkowych cenach”, „Za co kochamy zielone warzywa? Zawierają ogromną ilość witaminy C, żelaza oraz magnezu. Są również niskokaloryczne, więc możemy jeść je do woli. Ciekawi jesteśmy, które z poniższych najbardziej Wam smakują?”, „Chyba większość z nas odczuwa czasem ochotę na coś słodkiego. Chrupiące ciasteczka czy rozpływająca się w ustach czekolada? Dajcie znać w komentarzach, po co sięgacie w wolnych chwilach”. Supermarket Tesco, podobnie jak Biedronka, posługuje się dużą liczbą emotikonek na Facebooku. 
Wykorzystuje też emocje (Lubię to!, Super, Ha ha, Wow, Przykro mi, Wrr), aby dowiedzieć się od internautów, jakie są ich preferencje smakowe.

Na podstawie analizy działań marketingowych wybranych supermarketów można zauważyć, że wykorzystują one wiele technik, które mają przyciągnąć uwagę odbiorcy i zachęcić go do zrobienia zakupów właśnie w tej wybranej sieci sklepów. Autorem najciekawszej kampanii reklamowej w internecie jest obecnie Lidl, który każdego dnia publikuje kolorowe grafiki z pomysłowymi napisami. Wykorzystuje on potencjał networkingu społecznościowego, co ma wpływ na społeczne postrzeganie sklepu przez grupy docelowe.

\section{Bibliografia}

Diamond J., Diamond E. [2007], Merchandising - magnetyzm przestrzeni handlowej, tłum. E. Hahn, M. Strzelecka, Wydawnictwo Helion, Gliwice.

Filipek J. [2012], Od dyskontu do supermarketu. Rebranding Biedronki, http://brandvalue.pl/od-dyskontu-do-supermarketu-rebranding-biedronki (dostęp: 18.04.2018).

Kotler P., Armstrong G. [2012], Marketing. Wprowadzenie, tłum. D. Wąsik, Wolters Kluwer Polska, Warszawa.

Lewandowski M. [2017], Jedenaste. Nie bojkotuj, https://www.deon.pl/ religia/kosciol-i-swiat/komentarze/art,2939,jedenaste-nie-bojkotuj. html (dostęp: 18.04.2018).

Rak A. [2012], Kreowanie wizerunku marki w mediach społecznościowych, "Prace Naukowe Uniwersytetu Ekonomicznego we Wrocławiu”, nr 260, s. 407-416.

Reed J. [2011], Szybkie łącze z klientami. Marketing internetowy. Wszystko, co musisz wiedzieć, by wypromowaćswoja firmę w sieci, tłum. B. Sałbut, Wydawnictwo Helion, Gliwice. 